\title{
Are Cooperative Banks Not-for-Profit Organizations? A Hint from Seneca
}

\author{
Fuminobu Mizutani \\ Department of Business Administration, Kanto Gakuin University, Yokohama, Japan.
}

How to cite this paper: Fuminobu Mizutani. (2020) Are Cooperative Banks Not-for-Profit Organizations? A Hint from Seneca. Journal of Humanities, Arts and Social Science, 4(2), 89-93.

DOI: $10.26855 /$ jhass.2020.07.001

Received: July 28, 2020

Accepted: August 20, 2020

Published: August 26, 2020

*Corresponding author: Fuminobu Mizutani, Associate Professor, Department of Business Administration, Kanto Gakuin University, Yokohama, Japan. Email: fuminobu@kanto-gakuin.ac.jp

\begin{abstract}
Cooperative banks are often regarded as not-for-profit in accounting contexts today, a view that supports their legal status. De Beneficiis written by Seneca, an Ancient Roman philosopher with advanced knowledge on accounting, gives us hints to examine whether cooperative banks are not-for-profit, especially when his manuscript is read in Classical Latin. One rationale of tax exemption surrounding contemporary NFPs is the virtue of being not-for-profit, especially in relation to gifts. Seneca opposed earning interest from gifts, a thought informed by the virtue of Stoicism. Seneca's thinking indicates that the existence of dividends decides whether an organization is not-for-profit. Cooperative banks do not appear to be actually not-for-profit, though they contribute to public benefit.
\end{abstract}

Keywords

Seneca, Cooperative Bank, Not-for-Profit, Accounting, Gift

\section{Introduction}

Philanthropic investors rescued the Australian Associated Press (AAP) this year based on Ancient Roman thought. Acta Diurna were the mass media of Ancient Rome and promoted public benefit through journalism. Like Acta Diurna, the AAP was deemed valuable for industry and democracy by philanthropic investors. However, these philanthropic investors also possessed the contemporary notion of impact investing, a concept in accounting and finance, linking Ancient Roman thought with contemporary thought (Mason, 2020).

When we consider accounting-related aspects of not-for-profit organizations (NFPs), Ancient Roman thought gives us hints to consider, especially regarding public benefit as a requirement of NFPs. NFPs have three requirements that they are not-for-profit, provide a public benefit, and are independent according to commonly accepted theory.

Cooperative banks (CBs) are often classified as NFPs in various countries, though CBs can make dividends. Accounting scholars who classify CBs as NFPs recognize that CBs are not-for-profit with few exceptions. The word "CBs" is used in a broad sense to include credit unions. Costa and Da Silva (2019) and McKillop et al. (2020) areparticularly insightful papers in which CBs are regarded as NFPs. Costa and Da Silva (2019) was published in Financial Accountability \& Management: In Governments, Public Services and Charities, an influential journal about NFPs. McKillop et al. provided sharp-cut discussions about many topics on financial cooperative institutions, including CBs. We cannot neglect Costa and Da Silva and McKillop et al., though a commonly accepted theory of accounting is not-for-profit organizations should avoid dividends. Costa and Da Silva focused on CB in Italy, the heart of the Roman Empire. McKillop et al. (2020) referred to CBs in various countries, including the US.

The reason Costa and Da Silva classified CBs as NFPs seems to be that the amount of profit is not large, though Costa and Da Silva (2019) did not clarify why CBs are NFPs. McKillop et al. (2020) also classified CBs as NFPs 
because they do not aim for profit maximization, which is certainly true. McKillop et al. (2020) recognized that CBs make dividends, but did not think that this refuted CBs' not-for-profit status, especially in cases where there were ceilings on dividends rate. Whether CBs are not-for-profit is doubtful, though it is obvious that CBs promote public benefit and are independent. In considering whether CBs are really NFPs, we should consider whether this reason is supportive or not. Because whether an organization is not-for-profit affects its legal status in some countries, including the US, it is socially desirable to make a consistent definition for "not-for-profit". For example, McKillop (2020) referred to tax exemption related to whether an organization is not-for-profit.

This paper considers whether CBs are really NFPs based on the thought of Lucius Annaeus Seneca, a.k.a. Seneca the Younger. Many sciences, including social sciences, were developed in Ancient Rome. Seneca wrote De Beneficiis which was related to NFPs. The Platonic Academy in Athens was a famous NFP in the Julio-Claudian dynasty.

Prior literature includes Kass (2008), which examined De Beneficiis in the contemporary context, and Blanton (2013), which considered accounting based on Seneca's thoughts. However, both Kass and Blanton did not consider CBs from the perspective of Seneca's thought.

Kass (2008) was published in a series named Philanthropic and Nonprofit Studies, and cited paragraphs from De Beneficiis including Ben. 1.2.3. that were originally translated by A. Stewart for Kass (2008). Stewart's translation of Ben. 1.2.3. is exact. Stewart translated calendario, which is a declension of calendarium, as a ledger, though even Griffin and Inwood (2011), which this paper will refer in the next section, translated it as an account book in Ben. 1.2.3.

Because Kass focused on the fact that Seneca opposed aiming for economic return from beneficiaries, shequestioned if contemporary citizens should consider whether contributions bring social impact. Blanton insisted that it is not a virtue to make gifts with returns, even if the returns were supplemental and not economic; for example honor. Therefore, Blanton insisted that Seneca's thoughts on gifts written in De Beneficiis were not from virtue. Because Seneca did not oppose receiving supplemental rather than economic returns, as Blanton indicated, we can answer Kass's question with a "yes". The motivation of contribution bringing honor is probably regarded as a virtue in the contemporary U.S. by most citizens. Besides, gifts bringing honor did not deny virtue in the Greco-Roman world (Reeve, 2013). Thus, we can think that Seneca's thoughts on gifts were based in virtue.

There is a difference between Kass (2008) and Blanton (2013). Kass accepted Seneca' thoughts directly to the contemporary context, while Blanton insisted that Seneca adopted hyperbolic statements. De Beneficiis reflected Stoicism even if Seneca adopted hyperbolic statements, and Stoicism is insightful for contemporary citizens. Thus, we do not have to worry about which statements were hyperbolic or not.

Classical Latin was spoken in the western half of Ancient Rome, and Seneca also wrote his treatises in Classical Latin. While Seneca probably wrote his treatises entirely in uppercase letters, the widely-read manuscript of $D e$ Beneficiis is in the mixture of uppercase letters and lowercase. Thus, this paper distinguishes lowercase and uppercase letters. Certain periods of Classical Latin did not include $\mathrm{J}$ and $\mathrm{U}$; however, the widely-read manuscript of $D e$ Beneficiis includes $\mathrm{J}$ and $\mathrm{U}$, too. Thus, this paper distinguishes $\mathrm{J}$ from $\mathrm{I}$ and $\mathrm{U}$ from $\mathrm{V}$.

Seneca was a Stoic philosopher who taught Emperor Nero and was a financial practitioner who conducted financial activities in Britannia, part of the contemporary United Kingdom (Braund, 2015). Seneca was known for his humanistic thought and advocated improving the treatment of slaves even during the Ancient Roman era. During his reign, Nero became a tyrant who persecuted Christians, for example; however, when Seneca was teaching Nero early during his reign, Nero governed Roman citizens well. On the other hand, because Seneca leant a large amount as his financial activities, Celtics in Britannia were hostile toward him (Braund, 2015).

There is also evidence that indicates Seneca's impact on contemporary societies. An international conference called Seneca 2020 is scheduled to be held in Lisbon, which was a part of Hispania. A passage from De Beneficiis was selected as the preface of Kass (2008) from the wealth of literature on NFPs.

\section{Methodology and Materials}

Because we were looking for hints from history, we have adopted not a statistical method but an archival method, in the broad sense. While many accounting papers are written using statistical methods in the US, adopting an archival method to examine contemporary problems is common at the Academy of Accounting Historians, a section of the American Accounting Association.

The material examined in this paper includes all volumes of De Beneficiis by Seneca. It is thought that De Beneficiis was nearly complete by 64 A.D. De Beneficiis has been translated into English, such as On Benefits by Griffin 
and Inwood (2011), for example. According to Griffin and Inwood, existing manuscripts of De Beneficiis are not in perfect; however, this is inevitable because De Beneficiis was written long before the invention of the letterpress.

This paper mainly refers to a version of the manuscript in Classical Latin, provided by the Perseus Digital Library of Tufts University. As suggested by the name Perseus, this library mainly collects literature in Ancient Greek, but it also collects literature in Classical Latin and is focused on the classics. The National Endowment for the Humanities, a federal agency, provided support for this library in entering the text of this manuscript. The public sector in the US has, to a certain extent, recognized the value of this manuscript. We can assume this manuscript is widely read because the academic institution provides this manuscript reliably and free of charge for scholars. As a complement to the Latin manuscript, this paper refers to the English translation by Griffin and Inwood (2011), the most current academic translation of De Beneficiis, one that is readable for contemporary citizens and not esoteric.

\section{Discussion}

How Seneca thought about virtue related to gifts shows what it means to be not-for-profit. There is no single commonly accepted theory about the rationale for tax exemption surrounding contemporary NFPs (Bolton \& Mehran, 2006). One reason contemporary NFPs are exempt from taxation in various countries seems to be that being not-for-profit is considered a virtue. Of course, the main rationale of tax exemption is that NFPs are necessary for public benefit, but this cannot explain the differences between profit-oriented entities, which also contribute to public benefit, and NFPs. In order to explain these differences, we should focus not only on public benefit but also on whether an entity is not-for-profit, though the existence of these differences may be undesirable for contemporary citizens from a normative perspective. If the difference stems from being not-for-profit, contemporary citizens implicitly recognize being not-for-profit as a virtue. We should focus on virtue related to gifts, because tax exemption surrounding contemporary NFPs is particularly related to contribution, which is included in gifts.

Seneca's thoughts on accounting were theoretically advanced at that time, though some of his thoughts were too pessimistic to be adopted directly in practice. While his general remarks on accounting were pessimistic, his specific remarks were not.

Seneca wrote that the Cynic philosopher Demetrius said, "What is debt, what is a ledger, what is interest? Nothing but unnatural names for simple human greed" (Ben. 7.10.3.). Griffin and Inwood (2011) selected the word "ledger" in this part. In double-entry bookkeeping, both interest income and interest expense are nominal accounts. In double-entry bookkeeping, profit is merely a concept of surplus of revenues and expenses in a sense, though profit at profit-oriented entities has a raison d'etre because it shows the amount that could be allocated as dividends. Among scholars of classics, it is known that ledgers at that time were account books related to interest; for example, the latest Oxford Latin Dictionary explains calendarium under the topic of kalendarium. Among accounting historians, it is a commonly accepted theory that double-entry bookkeeping was invented in Italy during the Renaissance, thus, Seneca's thoughts on accounting were advanced to some extent.

The technical public finance term "on our discretionary budget" is in the original Classical Latin "in ultro tributis sit” (Ben. 4.1.2). Because Seneca used a technical term, we understand he was knowledgeable about accounting. Griffin (2013) explained this phrase, which she regards as a metaphor. However, gifts are always related to economic activity. Thus, this phrase was not a metaphor comparing non-economic activities to economic activities, but a metaphor comparing non-public finance to public finance.

As Griffin and Inwood (2011) translated, Seneca wrote that Demetrius would say, "These are evils, freely chosen and generated by our legal system; but there is nothing in them that eyes can see or that can be held in one's hand. These are dreams of pointless greed" (Ben. 7.10.4). Seneca's thoughts on accounting were too pessimistic for accounting practitioners.

Kass (2018) indicated us that Seneca regarded the lack of obligation for beneficiaries to repay as the characteristic of gifts. Seneca asserted that benefactors are loan-sharking if they request beneficiaries to repay, though this part was omitted in Kass (2018) (Ben. 1.2.3.). Loan-sharking is profit-oriented. Seneca appears to describe such benefactors as loan-sharking, because they have no right to request repayment, which directly opposes virtue. Seneca even used the words "greedy" and "shameful" about such requests. Seneca clearly stated that legal claims to repay gifts must not be permitted (Ben. 3.7.1. and 3.14.1).

Seneca insisted that, because gift-giving is virtuous, this noble activity should be done with delight for its own sake. Especially, in Classical Latin Seneca wrote "Rerum honestarum pretium in ipsis est” (Ben. 4.1.3.), which translates to, "The wage of honorable things is in themselves". We can guess that the word "wage" was used, because Seneca opposed not wages for certain activities, but interest on gifts. Seneca rhymed the phrase "Rerum honestarum pretium", 
which Griffin and Inwood translated to "The reward for honorable actions lies in the actions themselves", abandoning strictness to make the phrase readable for readers unfamiliar with Classical Latin. It is also remarkable that this sentence was in the same chapter where Seneca used the technical term mentioned above. Seneca opposed profit-seeking because it would deny an actionas a gift (Ben. 3.7.1.). Although Seneca denied beneficiaries' obligations to repay economically, he did not deny the ethical obligation to feel gratitude (Ben. 2.23.2.).

Seneca's thoughts prohibit not only interest on gifts, but also dividends on gifts, though Seneca used the word "interest" rather than "dividend". Seneca called gifts with interest loans, explaining that this expression was a metaphor (Ben. 4.12.1). Because all gifts are necessarily economic, we should construe this as a metaphor not because Seneca treated non-economic activities as economic activities, but because Seneca treated gifts as loans.

In order to protect Seneca's honor, we should keep in mind that Seneca knew the predecessor of the contemporary idea of distinguishing the net assets of NFPs from liabilities. Seneca knew that a duty to repay is characteristic of liabilities, as indicated by his usage of the Classical Latin word insolubile, which is a declension of insolubilis, meaning unrepayable. Seneca knew that gifts do not impose a duty to repay on the beneficiary (Ben. 4.12.1). A grammatical presupposition of the word insolubilis was not the existence of loans but existence of liabilities, though Seneca did not used the word "liabilities" in relation to this characteristic. When the NFP receives a contribution, which fall under gifts, the net assets of the NFP increases.

If virtue is valuable, CBs are actually profit-oriented, and the characteristic of a not-for-profit entity is not whether it aims to maximize profit but whether it makes dividends. On this point Costa and Da Silva (2019) and McKillop et al. (2020) seem to be wrong, though they are insightful reads for accounting scholars. Utilitarianism and Kantianism, which have influenced contemporary US thought, are different from virtue ethics. Utilitarianism and Kantianism do not necessarily require contemporary citizens to recognize virtue as valuable. However, for example, communitarianism recognizes virtue as valuable in the contemporary US., though there may be some differences between Stoicism and communitarianism. Of course, we cannot deny the other virtues CBs have.

\section{Conclusion}

According to Seneca's thoughts, the characteristic of not-for-profit appears to be not whether an organization aims to maximize profit, but whether it makes dividends. One rationale of contemporary tax exemption seems to be that it supports the virtue related to gifts when an organization is not-for-profit. CBs seem not to be not-for-profit, and while governments may wish to avoid tax exemption on organizations that make dividends, the fact that CBs bring public benefit can still be a rationale for tax exemption.

A limitation of this paper is the manuscript of De Beneficiis that exists today is not in perfect condition, as we have already mentioned, and that De Beneficiis was not primarily about NFPs themselves, but about charities and accounting by households and governments. This limitation is inevitable, because De Beneficiis was written before charitable organizations had become widely diffused, and because Seneca was not in the eastern half of Ancient Rome, where major academies such as the Platonic Academy existed, but in the western half.

Ancient Rome may be able to give us hints for contemporary accounting for NFPs. For example, we may be able to gain insight from Cicero's thoughts on charities, practices of tax exemption at the time, and Roman reception of Greek thought on gifts.

Seneca used the phrase "novas tabulas", a declension of novae tabulae (Ben. 1.4.6.), which translates literally to "new account books", though Griffin and Inwood (2001) translated this phrase without almost no financial aspect. This phrase was an idiom meaning "the writing of a debt". Much academic knowledge held by contemporary citizens owes to the Greco-Roman world, and thus contemporary citizens should not forget gratitude to Seneca and other philosophers of Ancient Rome.

\section{References}

Blanton, IV, T. R. (2013). The Benefactor's Account-Book: The Rhetoric of Gift Reciprocation according to Seneca and Paul. New Testament Studies, 59(3), 396-414.

Bolton, P., \& Mehran, H. (2006). An Introduction to the Governance and Taxation of Not-for-Profit Organizations. Journal of Accounting and Economics, 41, 293-305.

Braund, S. (2015). 1 - Seneca Multiplex: The Phases (and Phrases) of Seneca's Life and Words. In The Cambridge Companion to Seneca (pp. 15-28). New York: Cambridge University Press. 
Costa, E., \& Da Silva, G. G. (2019). Nonprofit Accountability: The Viewpoint of the Primary Stakeholders. Financial Accountability \& Management: In Governments, Public Services and Charities, 35(1), 37-54.

Griffin, M. T. (2013). Seneca on Society: A Guide to De Beneficiis. Oxford: Oxford University Press.

Griffin, M. T., \& Inwood, B. (trans.) (2011). On Benefits. Chicago: University of Chicago Press.

Kass, A. A. (ed.) (2008). Giving Well, Doing Good: Readings for Thoughtful Philanthropists. Bloomington: Indiana University Press.

Mason, M. (2020, July 6). How Ancient Rome Inspired a Newswire’s Escape from Death. Financial Review. https://www.afr.com/.

McKillop, D., French, D., Quinn, B., Sobiech, A. L., \& Wilson, J. O. S. (2020). Cooperative Financial Institutions: A Review of Literature. International Review of Financial Analysis, 71, Pages have been not clarified yet.

Reeve, C. D. C. (2013). Soul, Soul-Parts, and Persons in Plato. In Reason and Analysis in Ancient Greek Philosophy: Essays in Honor of David Keyt (pp. 197-209). Dordrecht: Springer. 